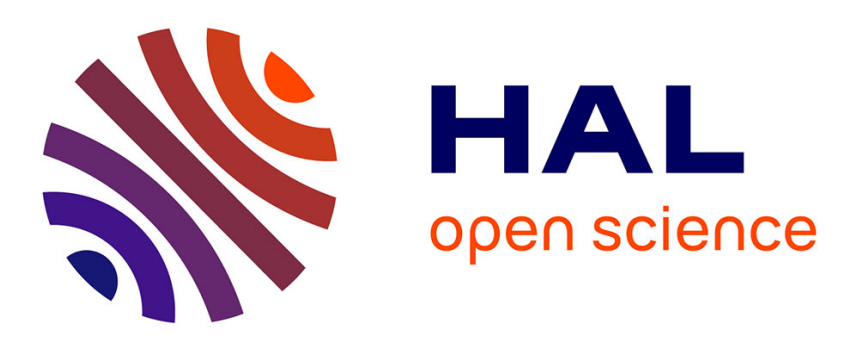

\title{
Diagnostic value of procalcitonin in acutely hospitalized elderly patients
}

\author{
Olivier Steichen, Eric Bouvard, Gilles Grateau, Sophie Bailleul, Jacqueline
}

Capeau, Guillaume Lefèvre

\section{To cite this version:}

Olivier Steichen, Eric Bouvard, Gilles Grateau, Sophie Bailleul, Jacqueline Capeau, et al.. Diagnostic value of procalcitonin in acutely hospitalized elderly patients. European Journal of Clinical Microbiology and Infectious Diseases, 2009, 28 (12), pp.1471-1476. 10.1007/s10096-009-0807-4 . hal-01171773

\section{HAL Id: hal-01171773 \\ https://hal.sorbonne-universite.fr/hal-01171773}

Submitted on 6 Jul 2015

HAL is a multi-disciplinary open access archive for the deposit and dissemination of scientific research documents, whether they are published or not. The documents may come from teaching and research institutions in France or abroad, or from public or private research centers.
L'archive ouverte pluridisciplinaire HAL, est destinée au dépôt et à la diffusion de documents scientifiques de niveau recherche, publiés ou non, émanant des établissements d'enseignement et de recherche français ou étrangers, des laboratoires publics ou privés. 


\section{Diagnostic value of procalcitonin in acutely hospitalized elderly patients}

Olivier Steichen $^{1,3}{ }^{*}$, Eric Bouvard $^{1 *}$, Gilles Grateau $^{1,3}$, Sophie Bailleul ${ }^{2}$, Jacqueline Capeau ${ }^{2,3}$, Guillaume Lefèvre ${ }^{2}$

* both authors contributed equally to this work

${ }^{1}$ AP-HP, hôpital Tenon, unité de gériatrie, médecine interne, 4 rue de la Chine, F-75020 Paris, France

${ }^{2}$ AP-HP, hôpital Tenon, biochimie et hormonologie, 4 rue de la Chine, F-75020 Paris, France

${ }^{3}$ Université Pierre et Marie Curie-Paris6, faculté de médecine, 15 rue de l'Ecole de Médecine, F75006 Paris, France

Corresponding author: Olivier Steichen

Service de médecine interne, hôpital Tenon,

4 rue de la Chine, 75020 Paris, France

Tel:+33156016033

Fax: +33156016077

e-mail: olivier.steichen@tnn.aphp.fr 


\begin{abstract}
The aim of this study was to evaluate procalcitonin as an adjunct to diagnose bacterial infections in older patients. One hundred and seventy two patients admitted to an acute-care geriatric unit during a 6-months period were prospectively included, 39 of them with an invasive bacterial infection. The best cutoff value to rule in a bacterial infection was $0.51 \mu \mathrm{g} / \mathrm{l}$ : sensitivity $64 \%$, specificity $94 \%$. The best cutoff value to rule out a bacterial infection was $0.08 \mu \mathrm{g} / \mathrm{l}$ : sensitivity $97 \%$, specificity $20 \%$.

Procalcitonin was inconclusive (between 0.08 and $0.51 \mu \mathrm{g} / \mathrm{l}$ ) for 112 admissions. Procalcitonin over $0.51 \mu \mathrm{g} / 1$ was useless 22 times out of 33 (infection already ruled in on clinical grounds) and misleading in 8 of the 11 remaining cases (no infection). Procalcitonin below $0.08 \mu \mathrm{g} / \mathrm{l}$ was useless 23 times out of 27 (infection already ruled out on clinical grounds) and misleading in 1 of the 4 remaining cases (infection). Despite a good overall diagnostic accuracy, the clinical usefulness of PCT to diagnose invasive bacterial infections in elderly patients hospitalized in an acute geriatric ward appears to be very limited.
\end{abstract}

\title{
KEYWORDS
}

Aged; Biological Markers/blood; Infection/diagnosis; Predictive Value of Tests; Sensitivity and Specificity 


\section{Introduction}

Reaching the diagnosis of bacterial infection is difficult in elderly patients. Medical history is often hard to get and unreliable, due to sensory loss, cognitive impairment, and social isolation.

Comorbidity interferes with physical examination and cardinal features of infection, like fever, are often missing. Microbiological samples are difficult to collect - for example sputum samples - and may be false positives - for example urine samples. Due to age-related changes, imaging studies are not easy to interpret. Underdiagnosis of bacterial infections leads to therapeutic delay and worse outcomes. By contrast, overdiagnosis exposes patients with viral infection or non-infectious inflammatory processes to unnecessary and potentially harmful antibiotics, and increases bacterial resistance in institutions and geriatric units.

A specific and easy to get biological marker of infection would help improving antibiotics prescription in older patients. Inflammation markers, such as C-reactive protein (CRP) and procalcitonin (PCT) have been extensively studied in children and adults, but not in elderly subjects. Studies in this age group have shown a lack of accuracy when cut-off values determined in children and younger adults were used [1].

Our aims were (i) to evaluate the overall diagnostic accuracy of an ultra sensitive PCT assay for invasive bacterial infections in acutely hospitalized elderly patients, (ii) to find the best cutoff values to sort low- and high-probability patients, and (iii) to evaluate the added value of PCT over clinical history and routine biological and radiological studies.

\section{Patients and Methods}

\section{Patients}

All consecutive admissions in a single 14-bed acute-care geriatric unit were prospectively considered for inclusion from $05 / 15 / 2007$. Patients had to be 75 years old or over to be admitted in the geriatric unit. The only exclusion criterion was antibiotic treatment for more than one day before admission, since PCT levels rapidly decrease following successful antibiotic therapy [2].

\section{Data and biological assays}

Clinical data were recorded at admission and blood tests were performed within 24 hours. The Charlson score was used to account for comorbidity [3]. Samples were collected on heparin lithium tubes for biochemical tests and EDTA for hematological tests (Becton Dickinson, Le Pont de Claix, France). PCT was measured in the blood sample drawn for other biochemical tests; no additional sample was drawn for this study. All biochemical tests except PCT were routinely performed with Architect ci8000 (Abbott Laboratories, Rungis, France), according to the manufacturers' instructions. CRP assays were determined by an immuno-turbidimetric method. For CRP, the detection limit was $0.02 \mathrm{mg} / \mathrm{l}$, the inter-assay coefficients of variation were $1.7 \%$ and $1.3 \%$ for values varying from 9.1 to $27 \mathrm{mg} / \mathrm{l}$, respectively. PCT was assayed with an automated Kryptor® analyzer at ultrasensitive level (B.R.A.H.M.S., Saint-Ouen, France) using TRACE technology [4]. The detection limit was $0.02 \mu \mathrm{g} / \mathrm{l}$, and the inter-assay coefficients of variation were 6.0 and $5.5 \%$ for values ranging from 0.20 to $9.70 \mu \mathrm{g} / \mathrm{l}$, respectively. PCT results were concealed until the end of study enrollment, data collection and final diagnosis assessment.

\section{Definitions}

Systemic inflammatory response syndrome (SIRS) was diagnosed according to the American College of Chest Physicians/Society of Critical Care Medicine consensus classification if two or more of the following were found: body temperature $>38^{\circ} \mathrm{C}\left(100.4^{\circ} \mathrm{F}\right)$ or $\left\langle 36^{\circ} \mathrm{C}\left(96.8^{\circ} \mathrm{F}\right)\right.$, heart rate $>90 / \mathrm{min}$, respiratory frequency $>20 / \mathrm{min}$, and leukocyte count $>12 \mathrm{G} / \mathrm{l}$ or $<4 \mathrm{G} / 1$ [5]. 
At the end of their hospitalization and without knowledge of procalcitonin results, patients were classified as having suffered from an invasive bacterial infection at admission or not. For the sake of clinical relevance, non-invasive bacterial infections, such as cystitis or bronchitis, were counted as non-diseased. Pyelonephritis and prostatitis were defined as fever or SIRS with urinary tract infections (WBC and bacterial CFU $>105 / \mathrm{ml}$ ) and either (i) blood cultures growing with the same pathogen, (ii) provoked loin or prostate pain, or (iii) no other obvious infection and fast clinical improvement under antibiotics. Pneumonia was defined as the association of fever or SIRS with at least one acute thoracic physical sign (dyspnea, cough, chest pain, purulent sputum, lung crackles) and a new radiographic pulmonary infiltrate on X-ray or CT-scan. Peritonitis was defined as fever or SIRS with acute abdominal pain (or tenderness) and guarding, and an underlying cause ascertained by radiological imaging or surgical intervention. Biliary infection was defined as fever or SIRS with acute abdominal pain or tenderness, and radiological features of cholecystitis or cholangitis (ultrasound or CT-scan). Intestinal infection was defined as fever or SIRS with acute abdominal pain and either growth of a bacterial pathogen (including $C$. difficile) in a stool sample or features of diverticulitis on CT-scan. Endocarditis was defined as fever or SIRS with positive blood-cultures and evidence of endocardial involvement on transthoracic echocardiography. Cellulitis was defined as fever or SIRS with acute redness and tenderness over a skin area.

\section{Outcomes}

The primary outcome was the area under the Receiving Operator Characteristic (ROC) curve of PCT for the diagnosis of invasive bacterial infection. Secondary outcomes were the comparisons between the area under the ROC curve of PCT and CRP, and the diagnostic accuracy of these variables. Since it was unlikely for a single cutoff value to perfectly distinguish between the presence and the absence of invasive bacterial infection, we chose to define two cutoff values for each PCT and CRP: a sensitive cutoff to rule out an invasive bacterial infection and a specific cutoff to rule it in. When a result is in the "gray zone" between these two cutoff values, it does not impact significantly the probability of invasive bacterial infection [6]. The number of patients in the gray zone was also considered among secondary outcomes, because the more they are, the less useful the diagnostic test is.

While making these primary analyses, it appeared that even when PCT or CRP levels were outside the gray zone, they were of little added value if the diagnosis of invasive bacterial infection was already obviously ruled in or ruled out on clinical grounds. Patients with levels of PCT or CRP below the sensitive cutoff who were obviously not suffering from an invasive bacterial infection were post hoc identified and counted. Similarly, patients with levels of PCT or CRP over the specific cutoff who were obviously suffering from an invasive bacterial infection were post hoc identified and counted. After review of their charts, patients were independently classified by two physicians as obviously infected, obviously non-infected or neither one. Disagreements were solved by consensus.

\section{Statistical methods}

Sample size computation was performed in order to achieve a standard error less than 0.05 for the area under the PCT ROC curve for the diagnosis of invasive bacterial infection, as proposed by Hanley and McNeil [7]. For this computation, the area was expected to be about 0.70 [1] and the first forty included patients were used to evaluate the prevalence of invasive bacterial infection in the study population.

Descriptive statistics are reported as median [interquartile range] or number (percentage), as appropriate, and differences were evaluated by the Mann-Whitney and the Chi-square tests, respectively. Area under the ROC curve for the diagnosis of invasive bacterial infection were computed for PCT and CRP and compared as proposed by Hanley and McNeil [8].

Sensitivity, specificity, positive and negative likelihood ratios, and diagnostic odds ratios were computed for the chosen cutoff values. The sensitive cutoff was defined in order to rule out an invasive bacterial infection, as the highest value for which the negative likelihood ratio was less 
than 0.1 or, if this first criterion could not be satisfied, for which the sensitivity was over $95 \%$. The specific cutoff was defined as the lowest value for which the positive likelihood ratio was over 10 or, if this first criterion could no be satisfied, for which the specificity was over $95 \%$. The specificities of PCT and CRP were compared at the sensitive cutoff values and their sensitivities at the specific cutoff values with the exact McNemar test for paired proportions. All statistical analyses were done with Stata 8.2 (StataCorp, Texas, USA).

\section{Results}

\section{Admissions features}

The prevalence of invasive bacterial infection among the first forty admissions was $25 \%$. Accordingly, a total number of 168 admissions were needed to ensure a standard error less than 0.05 for the area under the PCT ROC curve for the diagnosis of invasive bacterial infection, assuming an area of 0.70 at least. Recruitment lasted from 05/15/2007 to 11/16/2007 in order to achieve the required sample size. No viral epidemic (influenza, rotavirus, ...) occurred during this time period.

There were 195 admissions during the enrollment period but 23 of them were excluded because of antibiotics use for more than 24 hours. Features of the 172 included admissions are reported in Table 1. Eight patients were admitted twice during the study period. Thirty-nine admissions (23\%) were related to an invasive bacterial infection: 19 (46\%) pneumonia, $13(33 \%)$ pyelonephritis or prostatitis, 3 cellulitis (8\%), 1 diverticulitis (3\%), 1 cholecystitis (3\%), 1 angiocholitis (3\%), 1 endocarditis (3\%), and 1 peritonitis without etiological diagnosis (3\%). The main other reasons for admission were: falls 25 (14\%), left ventricular failure $16(9 \%)$, cancer complications $16(9 \%)$ and stroke $9(5 \%)$. No etiological diagnosis was reached for two patients admitted for acute fever that resolved quickly without antibiotics. These patients were classified in the group without invasive bacterial infection. Twenty-four hospitalizations (14\%) ended with the death of the patient.

\section{Diagnostic accuracy}

ROC curves of PCT and CRP for the diagnosis of bacterial infection are displayed in Figure 1. The areas under the ROC curve were 0.85 [95\% confidence interval: 0.77-0.92] for PCT and 0.84 [0.77$0.91]$ for CRP. These areas did not differ significantly $(\mathrm{p}=0.89)$.

The best cutoff values to exclude bacterial infection were $0.08 \mu \mathrm{g} / \mathrm{l}$ for PCT and $10 \mathrm{mg} / \mathrm{l}$ for CRP (Table 2). By construction, PCT and CRP had similar sensitivities for these cutoff values and the specificity of CRP was not significantly better $(\mathrm{p}=0.09)$.

The best cutoff values to affirm bacterial infection were $0.51 \mu \mathrm{g} / \mathrm{l}$ for PCT and $175 \mathrm{mg} / \mathrm{l}$ for CRP (Table 2). By construction, PCT and CRP had similar specificities for these cutoff values, but the sensitivity of PCT was significantly better $(\mathrm{p}=0.006)$.

\section{Diagnostic gain}

The number of patients in the gray zone was 112 (65\%) for PCT, whereas $27(16 \%)$ patients were below the sensitive cutoff $(0.08 \mu \mathrm{g} / \mathrm{l})$ and $33(19 \%)$ above the specific cutoff $(0.51 \mu \mathrm{g} / \mathrm{l})$. PCT below $0.08 \mu \mathrm{g} / \mathrm{l}$ was useless 23 out of 27 times (infection already ruled out on clinical grounds) and misleading in 1 of the 4 remaining cases (invasive infection: pyelonephritis). Likewise, PCT over $0.51 \mu \mathrm{g} / \mathrm{l}$ was useless 22 out of 33 times (infection already ruled in on clinical grounds) and misleading in 8 of the 11 remaining cases (no invasive infection: trauma 4, cancer 3 , and selfresolving fever 1). Overall, PCT was uninformative (gray zone or clinical examination already conclusive) for 157/172 (91\%) patients and misleading in $9(60 \%)$ of the 15 remaining. For CRP, the number of patients in the gray zone was $112(65 \%)$, whereas $40(23 \%)$ patients were below the sensitive cutoff $(10 \mathrm{mg} / \mathrm{l})$ and $20(12 \%)$ above the specific cutoff $(175 \mathrm{mg} / \mathrm{l})$. CRP below $10 \mathrm{mg} / \mathrm{l}$ was useless 36 out of 40 times (infection already ruled out on clinical grounds) and misleading in 1 of the 4 remaining cases (invasive infection: pneumonia). Likewise, CRP over 175 $\mathrm{mg} / \mathrm{l}$ was useless 13 out of 20 times (infection already ruled in on clinical grounds) and misleading 
in 5 of the 7 remaining cases (no invasive infection: cancer 3, trauma 2). Overall, CRP was uninformative (gray zone or clinical examination already conclusive) for 161/172 (94\%) patients and misleading in $6(55 \%)$ of the 11 remaining.

\section{Discussion}

\section{Principal findings}

In this study, PCT had a high overall accuracy for the diagnosis of invasive bacterial sepsis. However, when PCT was sufficiently high or low to be conclusive, infection could often be ruled in or out on clinical grounds alone. In a significant proportion of the remaining cases, procalcitonin results were misleading.

\section{Strengths and weaknesses of the study}

There were no other exclusion criteria than previous antibiotic treatment for more than 24 hours. The study population is therefore representative of the everyday recruitment of a geriatric unit. However, internal validity is hindered by some methodological limitations. First, there is no gold standard for the diagnosis of invasive bacterial infection and the definition of each type of invasive bacterial infection is controversial [9]. Nonetheless, initial and follow-up findings allow a robust diagnosis in most cases. Second, the classification of patients as obviously infected or obviously non-infected at their admission was done retrospectively. We tried to minimize the risk of bias by making two clinicians independently look at the files to classify patients and then resolve their disagreements by consensus.

\section{Comparison with previous studies}

PCT is a marker of severe bacterial but not viral infections [10]. Localized and non-severe bacterial infections fail to induce important increases of PCT levels $[11,12]$. Since PCT assays are not standardized, it is difficult to compare results from different studies. Two tests have been extensively assessed: the LUMItest ${ }^{\circledR}$ and the more recent Kryptor ${ }^{\circledR}$ assay. We used the latter, which belongs to the ultrasensitive assays [13].

Only three studies assessed the diagnostic value of PCT in older patients (Table 3). All these studies assessed a cutoff level of $0.5 \mu \mathrm{g} / \mathrm{l}$ but none used an ultrasensitive assay as we did. Two of these studies included patients hospitalized in geriatric wards [1,14]. The first one found a similar specificity of PCT (94\%) in patients with no bacterial infection but sensitivity was much lower (24\%) [1]. This lower sensitivity may be due to the assay that was used, since the proportion, site and severity of infections were very close to those found in our study. The second study found a similar sensitivity of PCT $(63 \%)$ in patients hospitalized for acute bacterial infections, but specificity was not reported [14]. The last study was done in an emergency department and assessed the accuracy of PCT to distinguish bacteremic from non-infected patients over 65 years old in whom blood culture were ordered [15]. Despite these major design differences with our work, the reported sensitivity and specificity were quite close. Overall, the authors of these three studies are very cautious and warn against reliance on PCT results to establish or exclude invasive bacterial infections in older patients.

We found two other studies assessing the diagnostic value of PCT for bacterial infections in hospitalized adults outside intensive care units, including some elderly patients $[16,17]$. The first one was done in an internal medicine department in patients with fever or biological inflammation [16]. Mean age of the patients was 68 years and a LUMItest ${ }^{\circledR}$ assay was assessed with a $0.5 \mu \mathrm{g} / \mathrm{l}$ cutoff to distinguish bacterial infections from non-infectious inflammatory processes. The reported sensitivity and specificity were 65 and $96 \%$ respectively, very close to our findings. The second study was done in younger patients (mean age 62 years) hospitalized in an infectious diseases department [17]. A LUMItest ${ }^{\circledR}$ assay was used with a $0.1 \mu \mathrm{g} / \mathrm{l}$ cutoff to diagnose bacterial infection in febrile patients. The sensitivity of PCT in patients with documented bacterial infections was only $54 \%$ and the specificity in non-infected patients was $70 \%$. Why PCT performed so poorly in this 
study is not clear. However, this is in keeping with a limited clinical usefulness of this test in patients hospitalized outside intensive care units.

\section{Conclusion}

Despite a good overall accuracy, when PCT was sufficiently high or low to be conclusive, infection could often be ruled in or out on clinical grounds alone. In a significant proportion of the remaining cases, PCT results were misleading. The clinical usefulness of PCT to diagnose invasive bacterial infections in elderly patients hospitalized in an acute geriatric ward appears to be very limited. 


\section{References}

1. Stucker F, Herrmann F, Graf JD, Michel JP, Krause KH, Gavazzi G (2005) Procalcitonin and infection in elderly patients. J Am Geriatr Soc 53:1392-1395.

2. Briel M, Schuetz P, Mueller B, Schild U, Nusbaumer C, Périat P, Bucher HC, Christ-Crain M (2008) Procalcitonin-guided antibiotic use vs a standard approach for acute respiratory tract infections in primary care. Arch Intern Med 168:2000-2007.

3. Charlson M, Szatrowski TP, Peterson J, Gold J (1994) Validation of a combined comorbidity index. J Clin Epidemiol 47:1245-1251.

4. Hubl W, Krassler J, Zingler C, Pertschy A, Hentschel J, Gerhards-Reich C, Mack M, Demant T (2003) Evaluation of a fully automated procalcitonin chemiluminescence immunoassay. Clin Lab 49:319-327.

5. The ACCP/SCCM American College of Chest Physicians/Society of Critical Care Medicine Consensus Conference (1992) Definitions for sepsis and organ failure and guidelines for the use of innovative therapies in sepsis. Crit Care Med 20:864-874.

6. Coste J, Pouchot J (2003) A grey zone for quantitative diagnostic and screening tests. Int J Epidemiol 32:304-313.

7. Hanley JA, McNeil BJ (1982) The meaning and use of the area under a receiver operating characteristic (ROC) curve. Radiology 143:29-36.

8. Hanley JA, McNeil BJ (1983) A method of comparing the areas under receiver operating characteristic curves derived from the same cases. Radiology 148:839-843.

9. Christ-Crain M, Müller B (2006) Procalcitonin : you only find what you look for, and you only look for what you know. J Am Geriatr Soc 54:546.

10. Mitaka C (2005) Clinical laboratory differentiation of infectious versus non-infectious systemic inflammatory response syndrome. Clin Chim Acta 351:17-29.

11. Rothenburger M, Markewitz A, Lenz T, Kaulbach HG, Marohl K, Kuhlmann WD, Weinhold C (1999) Detection of acute phase response and infection. The role of procalcitonin and C-reactive protein. Clin Chem Lab Med 37:275-279.

12. Giamarellos-Bourboulis EJ, Mega A, Grecka P, Scarpa N, Koratzanis G, Thomopoulos G, Giamarellou H (2002) Procalcitonin: a marker to clearly differentiate systemic inflammatory response syndrome and sepsis in the critically ill patient? Intensive Care Med 28:1351-1356.

13. Steinbach G, Rau B, Debard AL, Javourez JF, Bienvenu J, Ponzio A, Bonfà A, Hubl W, Demant T, Külpmann WR, Buchholz J, Schumann G (2004) Multicenter evaluation of a new immunoassay for procalcitonin measurement on the Kryptor System. Clin Chem Lab Med 42:440-449.

14. Dwolatzky T, Olshtain-Pops K, Yinnon AM, Raveh D, Rogowski O, Shapira I, Rotstein R, Berliner S, Rudensky B (2005) Procalcitonin in the elderly: normal plasma concentrations and response to bacterial infections. Eur J Clin Microbiol Infect Dis 24:763-765.

15. Caterino JM, Scheatzle MD, Forbes ML, D'Antonio JA (2004) Bacteremic elder emergency department patients: procalcitonin and white count. Acad Emerg Med 11:393-396.

16. Delèvaux I, André M, Colombier M, Albuisson E, Meylheuc F, Bègue RJ, Piette JC, Aumaître $\mathrm{O}$ (2003) Can procalcitonin measurement help in differentiating between bacterial infection and other kinds of inflammatory processes? Ann Rheum Dis 62:337-340.

17. Muñoz P, Simarro N, Rivera M, Alonso R, Alcalá L, Bouza E (2004) Evaluation of procalcitonin as a marker of infection in a nonselected sample of febrile hospitalized patients. Diagn Microbiol Infect Dis 49:237-241. 
Table 1. Features of the included 172 admissions in the acute-care geriatric unit.

\begin{tabular}{lccc} 
& $\begin{array}{c}\text { Without invasive bacterial } \\
\text { infection }(\mathrm{n}=133)\end{array}$ & $\begin{array}{c}\text { With invasive bacterial } \\
\text { infection }(\mathrm{n}=39)\end{array}$ & $\mathrm{p}$ \\
\hline Age $($ years $)$ & $86[82-92]$ & $85[81-90]$ & 0.58 \\
Females & $90(68 \%)$ & $20(51 \%)$ & 0.06 \\
Charlson score & $6[5-8]$ & $7[6-8]$ & 0.65 \\
Dementia & $55(41 \%)$ & $19(49 \%)$ & 0.41 \\
Body temperature (degrees Celsius) & $37.0[36.7-37.2]$ & $37.7[37.0-38.1]$ & $<0.001$ \\
Systolic blood pressure $(\mathrm{mmHg})$ & $139[120-158]$ & $130[110-150]$ & 0.03 \\
Heart rate $(/ \mathrm{min})$ & $80[70-91]$ & $84[73-92]$ & 0.33 \\
Respiratory rate $(/ \mathrm{min})$ & $20[18-24]$ & $24[20-30]$ & $<0.001$ \\
Total hemoglobin $(\mathrm{g} / \mathrm{l})$ & $116[104-125]$ & $109[102-123]$ & 0.17 \\
Blood white blood cell count $(\mathrm{G} / \mathrm{l})$ & $7.9[6.1-10.4]$ & $10.9[10.2-12.3]$ & 0.005 \\
Plasma sodium $(\mathrm{mmol} / \mathrm{l})$ & $140[137-142]$ & $140[136-144]$ & 0.88 \\
Plasma urea nitrogen $(\mathrm{mmol} / \mathrm{l})$ & $7[6-11]$ & $9[6-14]$ & 0.11 \\
Plasma creatinine $(\mu \mathrm{mol} / \mathrm{l})$ & $91[76-119]$ & $99[79-200]$ & 0.05 \\
Estimated $\mathrm{GFR}\left(\mathrm{ml} / \mathrm{min} / 1.76 \mathrm{~m}^{2}\right)$ & $60[46-71]$ & $53[28-72]$ & 0.19 \\
Total proteins $(\mathrm{g} / \mathrm{l})$ & $65[59-71]$ & $66[61-69]$ & 0.48 \\
C-reactive protein $(\mathrm{mg} / \mathrm{l})$ & $22[8-61]$ & $123[84-272]$ & $<0.001$ \\
Procalcitonin $(\mu \mathrm{g} / \mathrm{l})$ & $0.12[0.08-0.19]$ & $1.01[0.25-2.36]$ & $<0.001$ \\
\hline
\end{tabular}

Values are given as median [interquartile range] or number of admissions (percentage), as appropriate; GFR: glomerular filtration rate estimated by the simplified MDRD formula; there were no missing data except for respiratory rate in one patient. Medians were compared with the Mann-Whitney test and proportion with the Chi-square test. 
Table 2. Diagnostic properties of C-reactive protein (CRP) and procalcitonin (PCT) for invasive bacterial infection at their sensitive and specific cutoff values, along with the diagnostic properties of the systemic inflammatory response syndrome (SIRS) and its components.

\begin{tabular}{|c|c|c|c|c|c|c|c|c|c|}
\hline & $\mathrm{TP}$ & $\mathrm{FP}$ & $\mathrm{FN}$ & $\mathrm{TN}$ & Sensitivity & Specificity & NLR & PLR & DOR \\
\hline $\mathrm{PCT} \geq 0.08 \mu \mathrm{g} / 1$ & 38 & 107 & 1 & 26 & 97 [87-100] & $20[13-27]$ & $0.13[0.02-0.94]$ & $1.21[1.10-1.34]$ & 9.23 [1.53-inf] \\
\hline $\mathrm{CRP} \geq 10 \mathrm{mg} / \mathrm{l}$ & 38 & 94 & 1 & 39 & 97 [87-100] & $29[22-38]$ & 0.09 [0.01-0.62] & $1.38[1.22-1.56]$ & 15.77 [2.64-inf] \\
\hline PCT $>0.51 \mu \mathrm{g} / 1$ & 25 & 8 & 14 & 125 & 64 [47-79] & 94 [89-97] & $0.38[0.25-0.58]$ & 10.66 [5.23-21.71] & $27.90[10.72-72.53]$ \\
\hline $\mathrm{CRP}>175 \mathrm{mg} / \mathrm{l}$ & 15 & 5 & 24 & 128 & $39[23-55]$ & 96 [91-99] & $0.64[0.50-0.82]$ & $10.23[3.97-26.38]$ & $16.00[5.48-46.39]$ \\
\hline SIRS & 21 & 36 & 18 & 102 & 54 [37-70] & $74[66-81]$ & 0.62 [0.44-0.89] & 2.06 [1.38-3.09] & 3.31 [1.60-6.85] \\
\hline Body temperature $<36^{\circ} \mathrm{C}$ or $>38^{\circ} \mathrm{C}$ & 12 & 16 & 27 & 122 & $31[17-48]$ & 88 [82-93] & $0.78[0.63-0.97]$ & $2.65[1.37-5.13]$ & 3.39 [1.46-7.89] \\
\hline Heart rate $>90 / \mathrm{min}$ & 13 & 34 & 26 & 104 & $33[19-50]$ & $75[67-82]$ & $0.88[0.69-1.13]$ & $1.35[0.80-2.30]$ & $1.53[0.72-3.28]$ \\
\hline Respiratory rate $>20 / \mathrm{min}$ & 27 & 58 & 11 & 80 & $71[54-85]$ & $58[49-66]$ & $0.50[0.30-0.84]$ & $1.69[1.28-2.24]$ & $3.39[1.57-7.28]$ \\
\hline Blood WBC $<4$ G/1 or $>12 \mathrm{G} / 1$ & 16 & 33 & 23 & 105 & $41[26-58]$ & $76[68-83]$ & $0.78[0.59-1.02]$ & $1.72[1.06-2.77]$ & $2.21[1.06-4.65]$ \\
\hline
\end{tabular}

TP: true positives, FP: false positives, FN: false negatives, TN: true negatives, NLR: negative likelihood ratio, PLR: positive likelihood ratio, DOR: diagnostic odds ratio. 
Table 3. Diagnostic value of PCT in elderly patients.

\begin{tabular}{|c|c|c|c|c|c|c|c|}
\hline Reference & $\begin{array}{l}\text { Number of patients } \\
\text { (mean age in years) }\end{array}$ & Clinical settings & PCT assay & Compared groups & Cutoff $(\mu \mathrm{g} / \mathrm{l})$ & Sensitivity (\%) & Specificity $(\%)$ \\
\hline Stucker [1] & $218(85.4)$ & geriatric unit & LIAISON & $\mathrm{BI} /$ no BI & 0.5 & 24 & 94 \\
\hline \multirow[t]{2}{*}{ Dwolatzky [14] } & $80(82.3)$ & geriatric unit & LUMItest & $\mathrm{BI} /$ no BI & 0.5 & 63 & not reported \\
\hline & & & & & 2.0 & 30 & not reported \\
\hline \multirow[t]{2}{*}{ Caterino [15] } & $108(77)$ & emergency dep. & LUMItest & bacteremia / no infection & 0.2 & 93 & 57 \\
\hline & & & & & 0.5 & 57 & 83 \\
\hline
\end{tabular}

BI: bacterial infection 
Figure 1. Receiver Operating Characteristics (ROC) curves of CRP and PCT for the diagnosis of invasive bacterial infection in acutely hospitalized elderly.

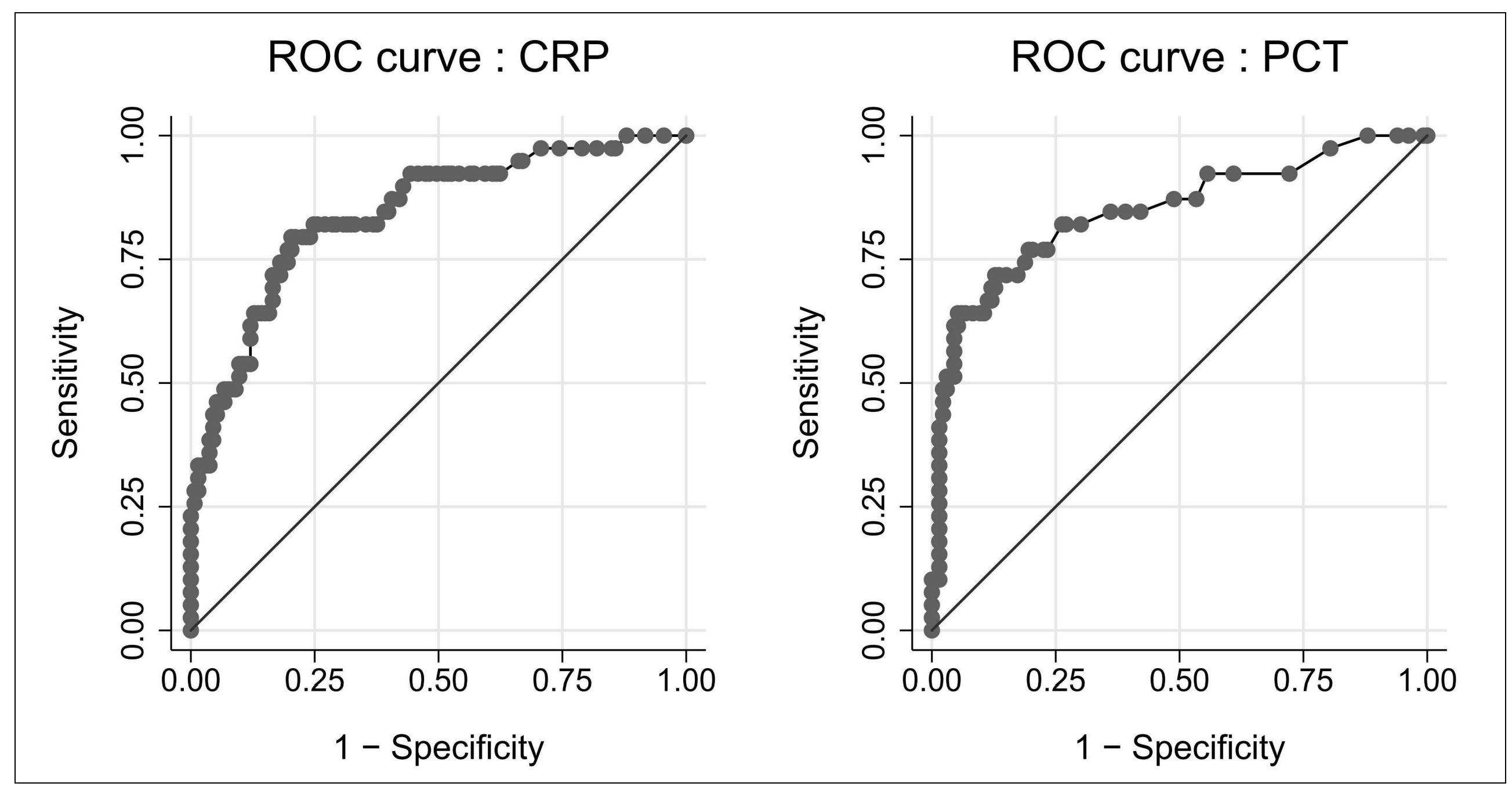

